\author{
УПРАВЛІННЯ ГРОШОВИМИ ПОТОКАМИ НА ПІДПРИЕМСТВІ \\ ПІД ЧАС COVID-19
}

\title{
CASH FLOW MANAGEMENT AT THE ENTERPRISE DURING COVID-19
}

УдК: 336.741

DOI: https://doi.org/10.32843/infrastruct54-33

\section{Волошина-Сідей В.В.}

к.е.н., старший викладач каредри фрінансів та обліку

Миколаївський національний університет імені В.О. Сухомлинського

Рудь І.ю.

к.е.н., доцент кафедри

фрінансів та обліку

Миколаївський національний університет

імені В.О. Сухомлинського

Портненко О.С.

магістрантка

Миколаївський національний університет

імені В.О. Сухомлинського

Voloshina-Sidey Victoria

V.O. Sukhomlynskyi National University

of Mykolaiv

Rud Inna

V.O. Sukhomlynskyi National University of Mykolaiv

Portnenko Olena

V.O. Sukhomlynskyi National University of Mykolaiv

\begin{abstract}
У статті досліджено основні теоретичні аспекти ефрективності та особливості управління грошовими потоками підприємства. Розкрито економічну сутність грошових потоків. Зроблено порівняння визначення «грошові потоки» від авторів у різних літературних джерелах і ссрормовано декілька загальних визначень. Висвітлено основні функції управління грошовими потоками, за допомогою яких підприємство реалізує головну мету і завдання системи управління грошовими потоками. Розглянуто основні завдання, що спрямовані на досягнення головної мети управління грошовими потоками підприємства. Надано рекомендації щодо джерел надходжень коштів до підприємства під час пандемії. $у$ статті особливу увагу прикуто до одного зі сценаріїв - моделювання грошових потоків, яке може допомогти есрективно оцінити бізнес під час COVID-19. Виконано аналіз одного зі сценаріїв у процесі управління грошовими потоками під час пандемії та зроблено висновок щодо корисності його використання.

Ключові слова: грошові потоки, грошові кошти, система управління грошовими потоками, ефективність управління грошовими потоками, пандемія COVID-19.
\end{abstract}

В статье исследованы основные теоретические аспекты эфрфективности и особенности управления денежными потоками предприятия. Раскрыта экономическая сущность денежных потоков. Проведено сравнение определения «денежные потоки» в различных литературных источниках и сформировано несколько общих определений. Освещены основные фрункции управления денежными потоками, с помощью которых предприятие реализует главную цель и задачи системы управления денежными потоками. Рассмотрены основные задачи, направленные на достижение главной цели управления денежными потоками предприятия. Даны рекомендации относительно источников поступлений средств на предприятие во время пандемии. Особое внимание уделено одному из сценариев моделированию денежных потоков, которое может помочь эфрфективно оценить бизнес при COVID-19. Выполнен анализ одного из сценариев при управлении денежными потоками во время пандемии и сделан вывод о полезности его использования. Ключевые слова: денежные потоки, денежные средства, система управления денежными потоками, эфрфрективность управления денежными потоками, пандемия COVID-19.

The article examines the main theoretical aspects of efficiency and features of enterprise cash flow management. The economic essence of cash flows is disclosed. A comparison is made of the definition of "cash flows" from authors in various literary sources and several general definitions are formed. The essence of the concept of cash flows is determined and the necessity of developing an effective method of cash flow management in the conditions of crisis and instability of cash inflows due to the limitations of "lockdown" is proved. One of the problems facing enterprises in modern conditions is restoration and preservation of the dynamics of the operating room cycles, investment and financial activities, which is the guarantee of the necessary liquidity position of the enterprise and the realization of its demand for money. The solution to this problem is impossible without in-depth studies of the economic mechanisms that determine the cash flows of each individual enterprise. It is intended that the efficiency of managing penny streams is due to the synchronization of overhead and viplat, on the basis of continuous platform capabilities of the enterprise and rational financial resources, which are called. Thus, there is a general need to develop methods of accounting, control and analysis of cash flows, increasing the scientific justification for making financial decisions in conditions of instability and risk, developing a system analytical and model tools for managing funds. The need to organize accounting, control and economic analysis of cash flows at enterprises is due to Lighting the main functions of cash flow management, with the help of which the company realizes the main goal and objectives of the cash flow management system. The main tasks aimed at achieving the main goal of cash flow management of the enterprise are considered. Recommendations are given regarding the sources of funds for enterprises during a pandemic. The article focuses on one of the scenarios, that is, cash flow modeling that can help to assess affectively a business under Covid-19. The analysis of one of the scenarios in cash flow management during a pandemic was carried out and a conclusion was made about the usefulness of its use.

Key words: cash flows, cash, cash flow management system, cash flow management efficiency, COVID-19 pandemic.

Постановка проблеми. Управління грошовими потоками в умовах кризи є основою виживання підприємства. Сьогодні у зв'язку з обмеженістю грошових ресурсів, зниженням рівня платоспроможності та нестійким фрінансовим станом багатьох підприємств через пандемію виникає необхідність у більш ефрективній організації системи та механізму управління грошовими потоками підприємства. Тому для управління грошовими потоками на підприємстві необхідно виокремити та систематизувати основні елементи, які мають вплив на ефективність управління ними.

Аналіз останніх досліджень і публікацій. Дослідженню питання управління грошовими потоками на підприємстві приділено значну увагу в наукових та публіцистичних працях як в Україні, так і за її межами. Упродовж останніх років вивченням цього питання займалися такі українські науковці та зарубіжні економісти: І.О. Бланк [2], Ф.Ф. Бутинець [3], А.Г. Загородній [4], Г.Л. Вознюк 
[4], Т.С. Смовженко [4], В.М. Гриньова, Г.Г. Кірейцев [5], І.А. Маркіна [8], А.М. Поддєрьогін [11], Нікбахт [10], А. Гроппеллі [10], М. Бертонеш [1], Р. Найт [1] та ін.

Постановка завдання. Метою дослідження $\epsilon$ аналіз економічної сутності та значення грошових потоків і визначення шляхів та джерел збільшення їх на підприємстві під час пандемії.

Виклад основного матеріалу дослідження. У сучасних умовах розвитку економіки в України грошові потоки $€$ основним об'єктом управління на кожному підприємстві. Рухом грошових потоків супроводжується здійснення будь-якої господарської діяльності. Причиною цього є ділові відносини підприємства з іншими юридичними особами, тобто між покупцями та замовниками, банками, постачальниками та підрядниками, бюджетом та позабюджетними фондами, а також із власним персоналом.

Різноманітність підходів до розуміння економічної сутності грошових потоків зумовлена тим, що вони становлять основу всієї фрінансової системи підприємства і мають тісний зв'язок фрактично з усіма його економічними процесами. Не існує єдиного визначення поняття «грошові потоки». У Міжнародному стандарті бухгалтерського обліку 7 «Звіт про рух грошових коштів» грошові потоки розкриваються як надходження та вибуття грошових коштів та їх еквівалентів [9]. А в економічній літературі автори це поняття трактують по-різному, приклади наведено в табл. 1.

Із наведених вище визначень можна зробити висновок, що грошовий потік підприємства являє собою сукупність розподілених у часі надходжень і виплат грошових коштів та їх еквівалентів, що генеруються його господарською діяльністю, рух яких пов'язаний із чинниками часу, ризику та ліквідності. Під грошовими коштами розуміється готівка у касі підприємства та кошти на його банківських рахунках, а під грошовими еквівалентами - короткострокові фрінансові інвестиції, які вільно конвертуються у грошові кошти і мають незначний ризик зміни вартості.

Грошові потоки, які срормуються на підприємстві у процесі його господарської діяльності, $€$ важливим самостійним об'єктом управління [2, c. 150].

Управління грошовими потоками підприємств це складний неперервний циклічний процес, який $€$ важливою складовою частиною системи управління його фрінансовою діяльністю. Під циклом управління грошовими потоками розуміється система послідовних етапів багаторазово повторюваного процесу прийняття і реалізації стратегічних та оперативно-тактичних рішень з управління грошовими потоками.

Основною метою управління грошовими потоками є забезпечення фрінансової рівноваги підприємства та фрормування необхідної звітності, що забезпечить проведення всебічного аналізу грошових потоків.

Аналіз руху грошових коштів дає можливість зробити більш обґрунтовані висновки про те, в якому обсязі та з яких джерел відбулося надходження на підприємство грошових коштів та які основні напрями їх використання. Метою аналізу $є$ оцінка здатності підприємства генерувати грошові потоки в обсягах та за строками здійснення необхідних планових платежів, забезпечення оптимізації грошового потоку.

Підходи до тлумачення поняття «грошові потоки»

Таблиця 1

\begin{tabular}{|l|l|l|}
\hline № & \multicolumn{1}{|c|}{ Автор } & \multicolumn{1}{|c|}{ Сутність грошових потоків } \\
\hline 1. & І.О. Бланк [2] & $\begin{array}{l}\text { Грошовий потік - сукупність розпділених у часі надходжень і виплат коштів, генерова- } \\
\text { них господарською діяльністю підприємства. }\end{array}$ \\
\hline 2. & Ф.Ф. Бутинець [3] & $\begin{array}{l}\text { Грошовий потік - найважливіший самостійний об'єкт фінансового аналізу, який прово- } \\
\text { диться з метою оцінки фрінансової стійкості та платоспроможності підприємства. }\end{array}$ \\
\hline 3. & Ю. Брігхем & $\begin{array}{l}\text { Грошовий потік - це фактичні чисті готівкові кошти, які надходять у фрірму чи витрача- } \\
\text { ються протягом деякого визначеного періоду. }\end{array}$ \\
\hline 4. & $\begin{array}{l}\text { А. Гроппеллі, } \\
\text { Е. Нікбахт [10] }\end{array}$ & $\begin{array}{l}\text { Грошовий потік - міра ліквідності підприємства, що складається з чистого доходу і без- } \\
\text { готівкових витрат, таких як амортизаційні відрахування. }\end{array}$ \\
\hline 5. & $\begin{array}{l}\text { А.Г. Загородній, } \\
\text { Г.Л. Вознюю, } \\
\text { Т.С. Смовженко [4] }\end{array}$ & $\begin{array}{l}\text { Грошовий потік - надходження (додатний грошовий потік) і витрачання (від'ємний гро- } \\
\text { шовий потік) коштів у процесі здійснення господарської діяльності підпрємства. }\end{array}$ \\
\hline 6. & Г.Г. Кірейцев [5] & $\begin{array}{l}\text { Грошовий потік є одним із ключових моментів оптимального співвідношення між } \\
\text { ліквідністю та прибутковістю. }\end{array}$ \\
\hline 7. & Б. Коласс [11] & $\begin{array}{l}\text { Грошовий потік - надлишок, який утворюється на підприємстві в результаті всіх опера- } \\
\text { цій, пов'язаних із господарською діяльністю. }\end{array}$ \\
\hline 8. & І.А. Маркіна [8] & $\begin{array}{l}\text { Грошовий потік - сукупність розподілених за часом надходжень і виплат грошових } \\
\text { коштів, які утворюютсся в процесі господарської діяльності і пов'язані із забезпеченням } \\
\text { його платоспроможності. }\end{array}$ \\
\hline 9. & А.М. Поддєрьогін [11] $]$ & $\begin{array}{l}\text { Грошовий потік можна визначити як сукупність послідовно розподілених у часі подій, } \\
\text { які пов'язані з відособленим та логічно завершеним фрактом зміни власника грошових } \\
\text { коштів у зв'язку з виконанням договірних зобов'язань між економічними агентами. }\end{array}$ \\
\hline
\end{tabular}


Висока роль ефективного управління грошовими потоками підприємства визначається такими основними положеннями:

- грошові потоки обслуговують здійснення господарської діяльності підприємства практично в усіх її аспектах;

- ефрективне управління грошовими потоками забезпечує фрінансову рівновагу підприємства в процесі його стратегічного розвитку;

- раціональне фрормування грошових потоків сприяє підвищенню ритмічності здійснення операційного процесу підприємства;

- есрективне управління грошовими потоками дає змогу скоротити потреби підприємства в позиковому капіталі;

- управління грошовими потоками $є$ важливим фрінансовим важелем забезпечення прискорення обороту капіталу підприємства;

- есрективне управління грошовими потоками забезпечує зниження ризику неплатоспроможності підприємства;

- активні методи управління грошовими потоками дають змогу підприємству отримувати додатковий прибуток, генерований безпосередньо його грошовими активами, а саме ефективне використання тимчасово вільних залишків коштів у складі оборотних активів, а також накопичуваних інвестиційних ресурсів у здійсненні фрінансових інвестицій [1, c. 130-132].

Основною метою управління грошовими потоками є забезпечення фрінансової рівноваги підприємства в процесі його розвитку шляхом збалансування обсягів надходження та витрат коштів й їх синхронізації [2, с. 280]. Основні завдання, що спрямовані на досягнення головної мети управління грошовими потоками підприємства:

1. Формування достатнього обсягу грошових ресурсів підприємства відповідно до потреб його фрінансово-господарської діяльності.

2. Оптимізація розподілу сформованого обсягу грошових ресурсів за видами господарської діяльності та основними напрямами їх використання.

3. Забезпечення високого рівня фрінансової стійкості підприємства в процесі його розвитку.

4. Підтримка платоспроможності підприємства на достатньо високому рівні.

5. Максимізація чистого грошового потоку для забезпечення необхідних темпів економічного розвитку підприємства на умовах самофрінансування.

6. Сприяння мінімізації втрат вартості грошових коштів у процесі їх фрінансово-господарського використання на підприємстві.

Система управління грошовими потоками підприємства реалізує свою головну мету і завдання шляхом виконання низки основоположних фрункцій (рис. 1).

Управління грошовими потоками передбачає цілеспрямований вплив на процеси акумуляції грошових коштів, їх витрачання та перерозподіл із метою забезпечення платоспроможності, фрінансової рівноваги, ритмічності та ефективності фрінансово господарської діяльності підприємства. У зв'язку з пандемією витрати на підприємстві повинні здійснюватися виходячи 3 наявних доходів компанії. Значна частина підприємств сьогодні переживає спад прибутків або зазнає збитків, тому для успішного подолання цієї кризи підприємства повинні мати у своєму розпорядженні достатню кількість грошових ресурсів.

Для підприємства важливо зрозуміти рівень своєї потреби в грошах, тобто коли вони надходять і коли виплачуються. Для цього потрібно створити декілька різних сценаріїв руху грошових коштів, які $є$ раціональним кроком для розуміння ймовірності та серйозності впливу. Підприємству треба визначити шляхи та джерела, за допомогою яких вони можуть збільшити свої грошові потоки. Тобто вони можуть включати в себе такі кроки, як збільшення доходів, скорочення або відстрочка витрат. Пандемія триває вже більше року, тому підприємства шукають інші джерела надходження коштів, деякі з них ми розглядаємо нижче.

1. Підприємства переглядають умови оплати за договорами з клієнтами, тобто вони заздалегідь установлюють розмір щомісячного грошового обороту або переходять на передоплату чи оплату протягом 5-10 днів від моменту виставлення рахунку.

2. Звертаються до податкових органів щодо забезпечення повернення, зменшення або відстрочки податкових платежів. Якщо в інших країнах компанії повинні сплачувати податок на прибуток протягом року, в Україні цей податок розраховуємо на підставі річного прибутку за попередній період, фрактичного квартального прибутку або очікуваного прибутку.

Такі дії призводять до значного зменшення навантаження на грошові потоки компанії. За нинішніх умов такий підхід уважається дієвим способом підтримки бізнесу, збереження робочих місць й уникнення більш істотних економічних збитків [7].

3. Також звертаються до банків із запитом щодо збільшення розміру боргового фрінансування, яке доступне для бізнесу. 3 огляду на потенційну рецесію, цілком імовірно, що центральні банки можуть знизити процентні ставки за позиками і розпочати певне пом'якшення грошово-кредитної політики. Знову ж таки, банки у низці країн убачатимуть у цьому можливість для себе і сприйматимуть цю ініціативу як елемент своєї корпоративної соціальної відповідальності, тому вони зможуть робити це за нижчими ніж зазвичай процентними ставками.

4. Наступний підхід став популярним під час попередніх економічних криз серед багатьох 
Основні фрункції управління грошовими потоками

Загальні фрункції управління грошовими потоками що характерні для будь-якої управлінської системи

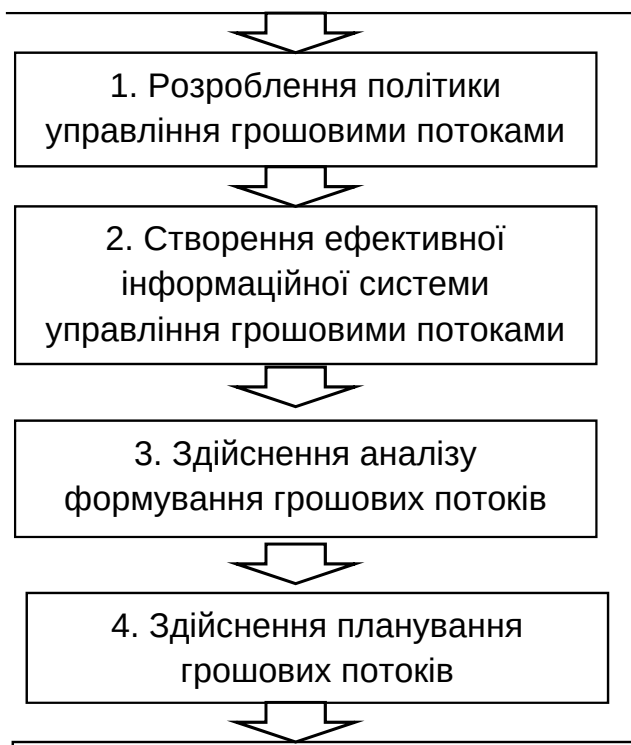

Специфрічні функції управління грошовими потоками як спеціальної сорери управління підприємством

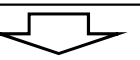

1. Управління грошовими потоками у процесі операційної діяльності підприємства

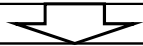

2. Управління грошовими потоками в процесі інвестиційної діяльності підприємства

3. Управління грошовими потоками у процесі фрінансової діяльності

5. Розроблення дієвої системи стимулювання реалізації прийнятих управлінських рішень щодо фрормування грошових потоків

6. Здійснення ефективного контролю над реалізацією прийнятих управлінських рішень щодо формування грошових потоків

Рис. 1. Основні функції управління грошовими потоками

приватних фрірм і він виявився досить успішним. Підприємства звертаються до уповноважених представників акціонерів задля надання бізнесу кредитів без застави [7].

5. Хоча це не є широко розповсюдженою практикою, все ж трапляються випадки, коли з метою забезпечення додаткового капіталу в деяких приватних фрірмах окремі власники за запитом можуть надати компанії власні акції або випустити акції компанії додатково. Це складний процес, що вимагає отримання згоди інших акціонерів на будь-яке істотне збільшення власного капіталу, а також призводить до довгострокового спотворення моделі розподілу акцій, що використовується у звичайні часи.

Як бачимо, сьогодні успішними та добре підготовленими до вирішення проблем, пов'язаних із рухом грошових коштів під час пандемії, виявилися ті фрірми, що на ранніх стадіях розробляють власні сценарії руху грошових коштів, плани управління грошовими потоками та які звертаються по допомогу до тих, хто може запропонувати швидкі та профресійні рішення [7].
Моделювання грошових потоків є одним зі сценаріїв у процесі управління грошовими потоками під час COVID-19. Моделювання може бути використано як ініціативний бізнес-підхід до оцінки поточних і майбутніх потреб у грошових потоках.

Моделювання грошових потоків здійснюється в двох напрямах:

- принципово важливо забезпечити можливість превентивного управління короткостроковими потребами в грошових коштах і максимально гнучкого прогнозування майбутніх грошових потоків з урахуванням тривожних часів і незвіданих шляхів, якими нам ще належить орієнтуватися в найближчі місяці;

- прогнозування грошових потоків також важливе під час звернення до зовнішніх сторін для покриття ваших потреб у фрінансуванні. Ви зможете визначити, який обсяг фрінансування потрібен за різними сценаріями, і розглянути різні варіанти фрінансування, а також доступні джерела фрінансування [14].

Процес моделювання починається 3 постановки питань для переконання, чи перебуваємо 
на правильному шляху чи ні. Під час подальшої підготовки моделі визначаємо ії̈ призначення.

Як тільки визначено її призначення, можна зрозуміти, які види інформації будуть потрібні для цього. Наприклад:

- Ви проводите аналіз беззбитковості?

- Оцінюєте ви свої короткострокові потреби в грошових коштах?

- Чи потрібне вам фрінансування або оцінка вашого бізнесу для цілей оцінювання?

- Оцінюєте ви вплив майбутніх перспектив зростання? [14]

Визначити вигляд надійної моделі можна за чотирма ключовими показниками стійкої моделі:

1. Чітко фрормулює ключові фрактори вашого бізнесу. Тобто показує конкретні важелі, за допомогою яких бізнес отримує вартість.

2. Ключові ресурси і прогнози (засновані на чинниках розвитку бізнесу) розділені. Це дає вам змогу змінювати ресурси у цей складний період, даючи змогу моделі бути гнучкою.

3. Інтегрована надійна модель. Звіт про прибутки і збитки, звіт про рух грошових коштів та бухгалтерський баланс сорормовано так, що вони взаємодоповнюють один одного (тристороння модель). Тристоронній прогноз забезпечує більшу цілісність і більш сприятливо сприймається за отримання доступу до фрінансування.

4. Надійна модель дає змогу проводити аналіз сценаріїв і оцінювати, який вплив буде на ваш бізнес залежно від різних сценаріїв [14].

Висновки 3 проведеного дослідження. Ураховуючи вищезазначене, можна сказати, що есрективність управління грошовими потоками визначається синхронізацією надходжень та виплат, підтримкою постійної платоспроможності підприємства та раціональним використанням фрінансових ресурсів, які фрормуються із зовнішніх і внутрішніх джерел.

Також із метою підвищення ефективності управління грошовими потоками на підприємствах необхідно:

- залучати в практику розрахунок системи показників грошових потоків як вимірників фрінансової стійкості та платоспроможності;

- досліджувати галузеві закономірності грошових потоків та враховувати їх у практиці обліку та аналізі підприємства;

- визначити потоки в обліковій, у тому числі оперативній, інформації для фрормування своєчасного та повного інформаційного забезпечення аналізу руху грошових коштів підприємств;

- удосконалювати методику аналізу грошових потоків.

Щоб ваша модель управління грошовими потоками залишалася цінною не тільки під час пандемії, важливо постійно її переоцінювати та правильно визначити орієнтири, щоб вони були якомога точнішими. Там, де допущення нестабільні, важливо зрозуміти ризик, запустивши низку сценаріїв. Хоча на це може знадобитися час, у довгостроковій перспективі це буде вигідно для підтримки вашого бізнесу і бізнес-планів.

\section{БІБЛІОГРАФІЧНИЙ СПИСОК:}

1. Бертонеш М., Найт Р. Управління грошовими потоками. Санкт-Петербург : Пітер, 2004. 240 с.

2. Бланк І.О. Фінансовий менеджмент : навчальний курс. Київ : Ніка-Центр, Ельга, 2004. 656 с.

3. Бутинець Ф.Ф. Економічний аналіз : навчальний посібник. Житомир : Рута, 2003. 680 с.

4. Загородній А.Г. Фінансовий словник. Київ : Знання, КОО, 2000. 587 с.

5. Кірейцев Г.Г. Фінансовий менеджмент : навчальний посібник. Київ : ЦУЛ, 2002. 496 с.

6. Коласса Б. Управління фрінансовою діяльністю підприємства. Проблеми, концепції і методи. Москва : Фінанси ; ЮНИТИ, 2017. 135 с.

7. Коронавірус (COVID-19): Рекомендації FIDIC для міжнародних інжинірингово-консалтингових компаній. URL: http://iceg.com.ua/wp-content/uploads/2020/ 04/FIDIC_UA_CV19.pdf (дата звернення: 20.04.2021).

8. Маркіна І.А. Менеджмент підприємства. Київ : Вища школа, 2020. 76 с.

9. Міжнародний стандарт бухгалтерського обліку 7. URL: https://zakon.rada.gov.ua/laws/show/929_01 9\#Tехt (дата звернення: 15.04.2021).

10. Нікбахт Е., Гроппеллі А. Фінанси / пер. 3 англ. В.Ф. Овсієнка та В.Я. Мусієнка. Київ : Основи, 1993. 383 с.

11. Поддєрьогін А.М. Фінансовий менеджмент : підручник. Київ : КНЕУ, 2005. 536 с.

12. Калінеску Т.В., Альошкін В.С., Кудіна В.Г. Фінансовий менеджмент : навчальний посібник. Луганськ : СНУ ім. В. Даля, 2010. 372 с.

13. Шляхи удосконалення системи управління грошовими потоками. URL: http://www.investplan.com.ua/ pdf/2_2017/11.pdf (дата звернення: 10.04.2021).

14. Як моделювання грошових потоків може допомогти ефрективно оцінити ваш бізнес у складний час. URL: https://www.bdo.ua/uk-ua/insights-2/informationmaterials/how-cash-flow-modelling-can-proactively-assess-your-business-in-uncertain-times (дата звернення: 10.04.2021).

\section{REFERENCES:}

1. Bertonesh M., Najt R. (2004) Upravlinnja ghroshovymy potokamy [Cash flow management]. SaintPetersburgh: Piter. (in Russian)

2. Blank I.A. (2004) Finansovyj menedzhment [Financial Management: Training Course]. Kyiv: NikaCentr, Eljgha. (in Ukrainian)

3. Butynecj F.F. (2003) Ekonomichnyj analiz [Economic analysis]. Zhytomyr: Ruta. (in Ukrainian)

4. Zaghorodnij A.Gh. (2000) Finansovyj slovnyk. Kyiv: T-vo "Znannja", KOO (in Ukrainian)

5. Kirejcev Gh.Gh. (2002) Finansovyj menedzhment. [Financial Management]. Kyiv: CUL. (in Ukrainian)

6. Kolassa B. (2017) Upravlinnja finansovoju dijaljnistju pidpryjemstva. Problemy, koncepciji i metody 
[Management of financial activities of the enterprise. Problems, concepts and methods]. Moscow: Finansy. (in Russian)

7. Koronovirus (COVID-19): Rekomendaciji FIDIC dlja mizhnarodnykh inzhynirynghovo - konsaltynghovykh kompanij [Coronavirus (COVID-19): FIDIC recommendations for international engineering and consulting companies]. Available at: http://iceg.com.ua/ wp-content/uploads/2020/04/FIDIC_UA_CV19.pdf (accessed 20 April 2021).

8. Markina I.A. (2020) Menedzhment pidpryjemstva [Enterprise management]. Vyshha shkola. (in Ukrainian)

9. Mizhnarodnyj standart bukhghaltersjkogho obliku 7 [International Accounting Standard 7]. Available at: https://zakon.rada.gov.ua/laws/show/929_019\#Text (accessed 15 April 2021).

10. Nikbakht E., Ghroppelli A. (1993) Finansy [Finance]. Kyiv: Osnovy. (in Ukrainian)
11. Poddjerjoghin A.M. (2005) Finansovyj menedzhment. Kyiv: KNEU. (in Ukrainian)

12. Kalinesku T.V., Aljoshkin V.S., Kudina V.Gh.. (2010) Finansovyj menedzhment: navch. posib. [Financial management: textbook. way]. Lughansk: Vyd-vo SNU im. V. Dalja. (in Ukrainian)

13. Shljakhy udoskonalennja systemy upravlinnja ghroshovymy potokamy [Ways to improve the cash flow management system]. Available at: http://www.investplan.com.ua/pdf/2_2017/11.pdf (accessed 10 April 2021).

14. Jak modeljuvannja ghroshovykh potokiv mozhe dopomoghty efektyvno ocinyty vash biznes u skladny] chas [How cash flow modeling can help effectively evaluate your business in difficult times]. Available at: https://www.bdo.ua/uk-ua/insights-2/information-materials/how-cash-flow-modelling-can-proactively-assessyour-business-in-uncertain-times (accessed 10 April 2021). 